Biological and Clinical Sciences Research Journal

ISSN: 2708-2261

www.bcsrj.com

DOI: https://doi.org/10.54112/bcsrj.v2020i1.14

Biol. Clin. Sci. Res. J., Volume, 2020: 14

Original Research

\title{
EFFECTS OF CARBOSULFAN ON THE BIOLOGY OF BIRD CHERRY OAT APHID
}

\author{
*AHMAD $\mathrm{S}^{1}$, HERA $\mathrm{Z}^{1}$, HANIF MS ${ }^{2}$, SYED AH ${ }^{3}$ \\ ${ }^{1}$ Institute of Agricultural Sciences, University of the Punjab, Lahore, Pakistan \\ ${ }^{2}$ Fodder Research Institute Sargodha, Sargodha, Pakistan \\ ${ }^{3}$ Department of Agricultural Entomology, University of Agriculture Faisalabad, Pakistan \\ *Corresponding author: shahbaz.ahmad@iags.pu.edu.pk, Zainabhera29@gmail.com
}

(Received, $2^{\text {nd }}$ May 2020, Revised $25^{\text {th }}$ June 2020, Published $4^{\text {th }}$ July 2020)

\begin{abstract}
Aphids are the most commonly occurring, destructive, sap sucking and serious threat to cereal crops especially wheat (Triticum aestivum). Bird Cherry Oat aphid Rhopalosiphum padi (L.), is one of the most important aphids on T. aestivum which is one of the most consumed food and a source of nutrition in Pakistan. It causes considerable yield loss in wheat. Carbosulfan, a carbamate, is of the most commonly used pesticide against R. padi. The effects of Carbosulfan on generations of $R$. padi were performed under standard lab conditions by exposing adult aphids to three different concentrations (1.4×10-7 ppm, $1.4 \times 10-10 \mathrm{ppm}, 1.4 \times 10-13 \mathrm{ppm})$ of Carbosulfan (Advantage $\left.{ }^{\circledR} E C\right)$. Based on the results, all three concentrations noticeably reduced the pre-adult survival rate. 1.4×10-13 significantly extended the development duration of 1 st instar, 2 nd instar and 3 rd instar nymphs. $1.4 \times 10$ 13 ppm also extended the total pre-adult period and female longevity of $R$. padi. The total longevity was increased by $1.4 \times 10-10 \mathrm{ppm}$. However, the fecundity decreased the most at $1.4 \times 10-10 \mathrm{ppm}$. While the TPRP and APRP increased the most at 1.4×10-13 ppm. In the life table parameters, both the intrinsic rate of increase $(r)$ and the finite rate of increase $(\lambda)$ decreased at $1.4 \times 10-7 \mathrm{ppm}$ and $1.4 \times 10-10 \mathrm{ppm}$, as well as the net reproductive rate (R0) also decreased at $1.4 \times 10-7 \mathrm{ppm}$ and $1.4 \times 10-10 \mathrm{ppm}$, while mean generation time $(T)$ showed increase at $1.4 \times 10$ $13 \mathrm{ppm}$. Thus, at the concentrations of Carbosulfan tested here, there were negative impacts on R. padi fitness and biology by decreased pre-adult survival rate, $\lambda, r$, and $R 0$. The concentrations also slowed down the development of some stages and extended T. My results would be helpful in assessing the overall effects of Carbosulfan on R. padi and should be taken into consideration when use Carbosulfan as a seed dressing insecticide for management of $R$. padi in wheat crop.
\end{abstract}

Keywords: Bird cherry oat aphid, Rhopalosiphum padi, Triticum aestivum, cereals, Carbosulfan

2007). It is widely distributed over Europe, Asia,

\section{Introduction}

Wheat is a staple food in Pakistan satisfying $80 \%$ of dietary needs with $38 \%$ share in caloric intake. Pakistan ranks eighth in terms of production in the world and is presently reaping production of over 25 million tons due to consolidated efforts of the farmers, policymakers and scientists. Over 152 varieties of wheat have been launched in Pakistan so far and a significant number of share from Punjab in the last decade; Punjab (69), Sindh (25), KP (44), Baluchistan (8), and PARC (6), respectively (Ahmad et al., 2017). Bird cherry-oat aphid, R. padi, is the most implicated aphid in the transmission of the barley yellow dwarf virus, among cereal aphids (Watson and Mulligan, 1960) which can dangerously reduce the yield of cereals (Watson, 1959).

Bird cherry oat aphid R. padi (L.), is one of the most financially important aphids on wheat (Akhtar et al.,
Africa and other countries such as Mexico, Canada, Australia, Brazil and Uruguay (CABI, 2019). Aphids are nearly transparent sucking insects with soft bodies. Aphids can induce premature death of leaves and yellowing when they are present in sufficient numbers. They secrete drops of sugary liquid known as "honeydew", which encourages the development of sooty molds on the leaves and causes tiny scorch. The life cycle of aphids involves wingless (apterous), sexual, winged (slates), and asexual forms. The females of most aphid species reproduce asexually (without being fertilized) when it feeds on cereals, giving rise to nymphs rather than eggs (Prescot et al, 1986). Attack of aphids also reduce canopy dry matter. Infestation of aphids also causes continuous yellowing in wheat from tillering stage to the end of flowering stage. Yellowing symptoms can be observed at the flower stage in wheat when aphids

[Citation: Ahmad, S., Hera, Z., Hanif, M.S., Syed, A.H., (2020). Effects of carbosulfan on the biology of bird cherry oat aphid. Biol. Clin. Sci. Res. J., 2020: 14 doi: https://doi.org/10.54112/bcsrj.v2020i1.14] 
feed for seven days (Roza-Gomes, 2008). R. padi damages plants both by removing their sap and by transmitting plant viruses (Close and Lamb, 1961; Greene, 1966; Harper and Blakeley, 1968). Usually aphid feeding causes poor root growth and a decrease in tiller number but in spring heavy infestations can kill young plants (Russell, 1978). They can reduce grain yield, thousand-kernel mass, and quality also (Rautapaa, 1968). Feeding during the seedling (2leaf) stage causes largest reductions in yield causing a yield loss upto 40-60\%, with mean densities of 1020 aphids/tiller (Kantack and Kieckhefer, 1979). Plant physiology is affected in different ways by sieve diversion by numerous aphids, depending on the plant growth stage at time of infestation. The most common reaction in fruit trees is twig stunting due to reduced growth. Bad fructification in flowers is also a result of aphid feeding (flower abortion). Fruits can be smaller if aphids' colonies develop later. Most of these injuries by aphids are 'asymptomatic' (Quisenberry and $\mathrm{Ni}$ 2007) Carbosulfan has been observed to significantly lower the population of $R$. padi on wheat (Faheem et al., 2016). Carbosulfan has also been shown to cause highest population reduction when compared with other insecticides such as imidacloprid, acetamiprid and thiamethoxam etc. (Ahmad et al., 2017). Hence, this approach was adopted to study the population responses of $R$. padi when exposed to Carbosulfan. The main objective of the current study was to gain a better understanding about how very low concentrations of Carbosulfan affect the development, reproduction, and survival of $R$. padi.

\section{Materials and methods}

Insects

$R$. padi adults were collected from wheat fields at Ayub Agricultural Research Institute (coordinates), Faisalabad, Pakistan. Collection sites were selected based on insecticide usage history, seed dressing history and varietal differences. Field collected aphids before exposing, were kept in laboratory for few hours to attain homogeneity and to ensure pathogen and ectoparasites free culture.

\section{Insecticide}

Carbosulfan (Advantage ${ }^{\circledR}$ 20EC) by FMC ${ }^{\circledR}$ was used in the experiment.

\section{Bioassay}

Leaf dip method was used for bioassay with some modifications (Sawicki and Rice 1978). Insecticide solution was prepared by taking $5 \mu \mathrm{L}$ amount of insecticide from insecticide bottle and added in $250 \mathrm{ml}$ water to attain required volume. Serial dilution was done to attain required concentrations. Experimental design CRD was adapted under controlled lab conditions: $23 \pm 1{ }^{\circ} \mathrm{C}, 60 \pm 10 \%$ relative humidity $(\mathrm{RH})$. There were three concentrations, every concentration had three replicates. Fresh leaves were collected from wheat field at AARI, washed and cleaned. After that leaves were cut in smaller sizes, dipped into insecticide solution and left to dry for 1-2 hours. The dried leaves were placed into Petri plates on filter papers. 30 insects were exposed at every concentration $\left(1.4 \times 10^{-7} \mathrm{ppm}, 1.4 \times 10^{-10} \mathrm{ppm}, 1.4 \times 10^{-13} \mathrm{ppm}\right)$. Data was collected after every 24 hours till 8-10 days. Every specimen of adult aphids and their newly young ones were separated after 24 hours, one specimen was kept into one petri plate to check proper effects of the insecticide. The aphids were observed under microscope, the live aphids were given fresh food and the dead aphids were disposed of.

\section{Analysis}

The basic life parameter such as age-specific fecundity $\left(m_{x}\right)$, age-specific survival rate $\left(l_{x}\right)$, agespecific maternity $\left(l_{x} m_{x}\right)$, intrinsic rate of increase $(r)$, finite rate of increase $(\chi)$, mean generation time $(T)$, net reproductive rate $\left(R_{0}\right)$, TPRP and APRP were calculated using the computer program TWOSEXMS Chart (Chi, 2017).

\section{Results}

According to biological parameters of $R$. padi (Table 1), $1.4 \times 10^{-13} \mathrm{ppm}$ could significantly increase the survival period of 1st instar nymphs (N1), 2nd instar (N2) nymphs and 4th instar (N4) nymphs. In contrast $1.4 \times 10^{-10} \mathrm{ppm}$ significantly increased the survival period of 3rd nymph instar (N3). Total pre adult period increased significantly in $1.4 \times 10^{-13} \mathrm{ppm}$. There was significant increase in pre-adult survival rate and the female longevity at $1.4 \times 10^{-13} \mathrm{ppm}$. However, total longevity rose more at $1.4 \times 10^{-10} \mathrm{ppm}$ $(5.06 \pm 0.46)$ as compared to $1.4 \times 10^{-7} \mathrm{ppm}$ $(4.09 \pm 0.53)$ and $1.4 \times 10^{-13} \mathrm{ppm} \quad(4.80 \pm 0.73)$. According to (Table 2$)$, fecundity $(9.45 \pm 1.99)$ was significantly increased at $1.4 \times 10^{-13} \mathrm{ppm}$. The Total pre reproductive period (TPRP) and the Adult pre reproductive period (APRP) increased the most at $1.4 \times 10^{-13} \mathrm{ppm}$. However, there was a significant decrease in Total pre reproductive period (TPRP) $(6.78 \pm 0.28)$ and Adult pre reproductive period (APRP) $\quad(0.11 \pm 0.11)$ at $1.4 \times 10^{-7} \mathrm{ppm}$. The reproductive duration of female aphids increased the most at $1.4 \times 10^{-7} \mathrm{ppm}$. According to the life table parameters of $R$. padi (Table 3), the mean generation time $(T)$ at $1.4 \times 10^{-13} \mathrm{ppm}(10.61 \pm 0.48)$ was longer as compared to $1.4 \times 10^{-7} \mathrm{ppm}(9.15 \pm 0.92)$ and $1.4 \times 10^{-10}$ ppm $(9.37 \pm 1.39)$. Net reproductive rate $\left(R_{0}\right)$ was significantly decreased by $1.4 \times 10^{-7} \mathrm{ppm}(1.66 \pm 0.55)$ and $1.4 \times 10^{-10} \mathrm{ppm}(1.18 \pm 0.33)$ in comparison to $1.4 \times 10^{-13} \mathrm{ppm}(2.6 \pm 0.84)$. The intrinsic rate of increase $(r)$ and Finite rate of increase $(\tau)$ of aphids at $1.4 \times 10^{-7} \mathrm{ppm}$ and at $1.4 \times 10^{-10} \mathrm{ppm}$ was significantly 
reduced as compared to $1.4 \times 10^{-13} \mathrm{ppm}$ where they increased distinctively.

Table 1: Effect of different concentrations of carbosulfan on preadult developmental duration, preadult survival and longevity of $R$. padi

\begin{tabular}{lllllll}
\hline Parameter (days) & $\mathbf{n}$ & $\mathbf{1 . 4 \times 1 0 ^ { - 7 }} \mathbf{p p m}$ & $\mathbf{N}$ & $\mathbf{1 . 4 \times \mathbf { 1 0 } ^ { - 1 0 }} \mathbf{p p m}$ & $\mathbf{n}$ & $\mathbf{1 . 4 \times 1 \mathbf { 1 0 } ^ { - 1 3 } \mathbf { p p m }}$ \\
\hline $\mathbf{N}_{\mathbf{1}}$ & 19 & $1.89 \pm 0.2$ & 30 & $1.83 \pm 0.13$ & 17 & $1.94 \pm 0.16$ \\
$\mathbf{N}_{\mathbf{2}}$ & 14 & $1.93 \pm 0.13$ & 20 & $1.7 \pm 0.15$ & 12 & $2.00 \pm 0.25$ \\
$\mathbf{N}_{\mathbf{3}}$ & 9 & $1.56 \pm 0.18$ & 15 & $2.07 \pm 0.15$ & 11 & $1.73 \pm 0.24$ \\
$\mathbf{N}_{\mathbf{4}}$ & 9 & $1.67 \pm 0.33$ & 11 & $1.55 \pm 0.21$ & 11 & $2.36 \pm 0.20$ \\
Total pre-adult & 9 & $6.67 \pm 0.29$ & 11 & $6.91 \pm 0.16$ & 11 & $8.27 \pm 0.24$ \\
Pre-adult survival & & $0.2 \pm 0.05$ & & $0.22 \pm 0.05$ & & $0.27 \pm 0.07$ \\
Female longevity & 9 & $10.22 \pm 0.62$ & 11 & $10.27 \pm 0.3$ & 11 & $12 \pm 1.26$ \\
Total longevity & 45 & $4.09 \pm 0.53$ & 50 & $5.06 \pm 0.46$ & 40 & $4.80 \pm 0.73$ \\
\hline
\end{tabular}

Where $=\mathrm{N}_{1}-\mathrm{N}_{4}$ indicates the $1^{\text {st }}$ to $4^{\text {th }}$ instar nymphs of $R$. padi

Table 2: Effect of different concentrations of carbosulfan on fecundity and reproduction of $R$. padi

\begin{tabular}{|c|c|c|c|}
\hline Parameter & $1.4 \times 10^{-7} \mathrm{ppm}$ & $1.4 \times 10^{-10} \mathrm{ppm}$ & $1.4 \times 10^{-13} \mathrm{ppm}$ \\
\hline Fecundity (nymph/female) & $8.33 \pm 1.3$ & $5.36 \pm 0.56$ & $9.45 \pm 1.99$ \\
\hline TPRP & $6.78 \pm 0.28$ & $7.27 \pm 0.24$ & $8.73 \pm 0.27$ \\
\hline APRP & $0.11 \pm 0.11$ & $0.36 \pm 0.15$ & $0.45 \pm 0.16$ \\
\hline Reproductive duration & $3.22 \pm 0.32$ & $2.91 \pm 0.28$ & $3.18 \pm 0.35$ \\
\hline
\end{tabular}

Where, $\mathrm{TPRP}=$ Total pre-reproductive period, $\mathrm{APRP}=$ Adult pre-reproductive period

Table 3: Effect of different concentrations of carbosulfan on life table parameters of $R$. padi

\begin{tabular}{|c|c|c|c|c|}
\hline Parameter & & $1.4 \times 10^{-7} \mathrm{ppm}$ & $1.4 \times 10^{-10} \mathrm{ppm}$ & $1.4 \times 10^{-13} \mathrm{ppm}$ \\
\hline Mean generation time $T$ (day) & & $9.15 \pm 0.92$ & $9.37 \pm 1.39$ & $10.61 \pm 0.48$ \\
\hline $\begin{array}{lrl}\text { Net } & \text { reproductive } & \text { rate } \\
\text { (offspring/individual) } & \end{array}$ & $R_{0}$ & $1.66 \pm 0.55$ & $1.18 \pm 0.33$ & $2.6 \pm 0.84$ \\
\hline Intrinsic rate of increase $r\left(d^{-1}\right)$ & & $0.0557 \pm 0.0407$ & $0.0176 \pm 0.0329$ & $0.0900 \pm 0.0331$ \\
\hline Finite rate of increase $\lambda\left(d^{-1}\right)$ & & $1.0573 \pm 0.0419$ & $1.0178 \pm 0.0329$ & $1.0942 \pm 0.0357$ \\
\hline
\end{tabular}

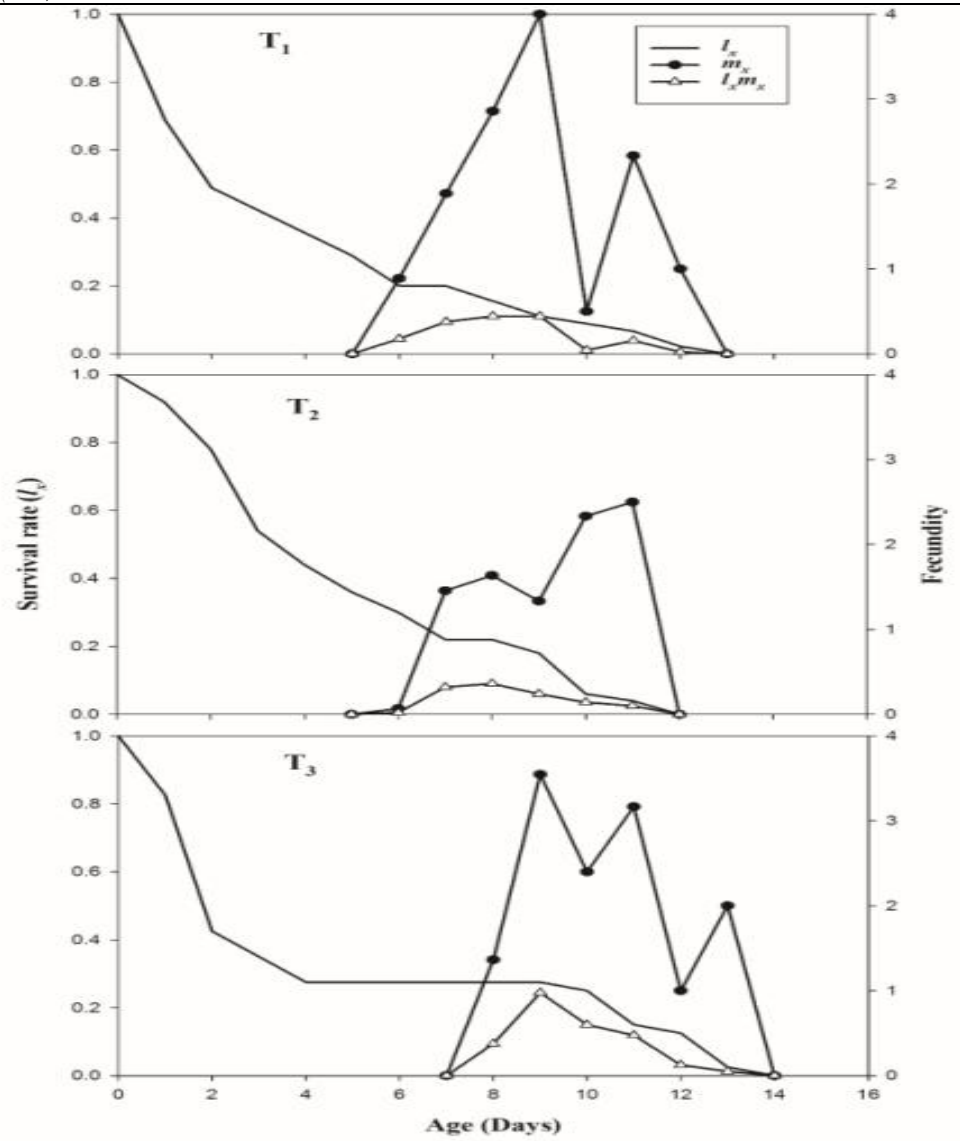

[Citation: Ahmad, S., Hera, Z., Hanif, M.S., Syed, A.H., (2020). Effects of carbosulfan on the biology of bird cherry oat aphid. Biol. Clin. Sci. Res. J., 2020: 14 doi: https://doi.org/10.54112/bcsrj.v2020i1.14] 
Figure: 1. Age specific survival rate $\left(l_{x}\right)$, age-specific fecundity $\left(m_{x}\right)$ and net maternity $\left(l_{x} m_{x}\right)$ of $R$. padi were tested on different concentrations of carbosulfan

The age-specific fecundity, age-specific survival rate and net maternity for each of the three treatments are shown in Fig. 1. At concentration $1.4 \times 10^{-7} \mathrm{ppm}$ there was significant decrease in the age specific survival rate $\left(l_{x}\right)$, on the other hand the age-specific fecundity rate $\left(m_{x}\right)$ showed some fluctuation as it increased at one point but dropped and then increased again. The age specific maternity $\left(l_{x} m_{x}\right)$ increased uniformly for some time but then started to fluctuate. At concentration $1.4 \times 10^{-11} \mathrm{ppm}$ age-specific survival rate $\left(l_{x}\right)$ of $R$.padi decreased with the passage of time and age-specific fecundity $\left(m_{x}\right)$ rate showed minor fluctuations and did not change drastically. The age specific maternity $\left(l_{x} m_{x}\right)$ displayed a flat curve. At concentration $1.4 \times 10^{-14} \mathrm{ppm}$ age-specific survival rate $\left(l_{x}\right)$ of the aphids decreased but then became constant for some time and then slowly decreased again, while the age-specific fecundity $\left(m_{x}\right)$ rate showed large fluctuations. The age-specific maternity $\left(l_{x} m_{x}\right)$ increased drastically and then decreased periodically (Fig.1).

\section{Discussion}

Carbosulfan [2,3-dihydro-2 2-dimethylbenzofuran-7yl (dibutylaminothio) methylcarbamate] is a broadspectrum carbamate pesticide which inhibits the activity of acetylcholinesterase. It is used to control mites, insects and nematodes by foliar, seed and soil treatment applications, foliar pests can be controlled via systemic action by soil applications, andthrough direct conta ct or stomach ingestion is said to be effective (FAO/WHO 1984), 1984).Carbosulfan (Advantage 20EC) acts as the most effective insecticide for the control of aphids on Wheat. The present study was to check the severity of effects of various concentrations of carbosulfan (advantage 20EC) on $R$. padi in terms of the fecundity rate, survival rate, adult longevity and age specific maternity.

My results of bioassay in laboratory showed significant differences in mortality and fecundity of $R$. padi feeding on the plants. Total pre adult period and the preadult survival showed maximum increase at $1.4 \times 10^{-13} \mathrm{ppm}$. The female longevity and the total longevity increased the most at $1.4 \times 10^{-13} \mathrm{ppm}$. The nymph instars exposed to $1.4 \times 10^{-7} \mathrm{ppm}$ and $1.4 \times 10^{-10}$ ppm showed lower values of TPRP and APRP. At lowers concentration $\left(1.4 \times 10^{-13} \mathrm{ppm}\right)$ net reproductive rate $\left(R_{0}\right)$ is more as compared to other two concentrations. Effect on biology with respect to fecundity $(5.36 \pm 0.56)$ was recorded highest in exposure to concentration $\left(1.4 \times 10^{-10} \mathrm{ppm}\right)$ at it decreased the most at that concentration. In life table parameters measurement, it was noted that intrinsic rate of increase and finite rate of increase were highest at 3rd concentration $\left(1.4 \times 10^{-13} \mathrm{ppm}\right)$ in the larval life span. The mean generation time $(T)$ and the net reproductive rate $\left(R_{0}\right)$ also increased at $1.4 \times 10^{-13}$ ppm. Torres and Ruberson (2004) support my results that, all nymph instars (N1, N2, N3, N4) are affected more at higher concentration and their survival rate is more at lower. All three concentrations used in experiment had significant impact on aphid population when compared with control plot. Maximum population reduction was observed in T2 with application of Advantage 20 EC @ 300 ml/acre and proved to be more effective insecticide against the canola aphid, L. erysimi Kalt. as compared to other insecticides succeeded by T1 with Actara 25 WP @ 24 g/acre, T3 with Confidor 200 SL @ 150 ml/acre and T4 with Mospilan 20 SP @ 80 g/acre (Ahmad et al., 2017). Sublethal concentrations of insecticides like carbofuran and bifenthrin are shown to have negative effects on aphid's population growth and biology as the concentrations increase (Kerns and Stewart 2000). Calafiori et al. (1999) reported that carbosulfan@0.6 L ha-1 provided more than 80\% control of aphids and thrip in cotton. Chinnaiah and Asif (1999) reported that carbosulfan@25 g a.i kg-1 seed reduced the number of sucking pests of cotton such as leafhoppers and aphids after sowing up to 45 days. Moreover, $R$. padi was more susceptible to all insecticides than $S$. avenae and $S$. graminum and all the insecticides were more effective against $R$. padi than $S$. avenae and $S$. graminum. However, malathion, bifenthrin, imidacloprid, pymetrozine, carbosulfan and thiamethoxam significantly decreased the population of $R$. padi (Faheem et al., 2016). When R. padi aphids fed on leaves of wheat treated with sublethal concentrations of insecticides, their xylem feeding was reduced. Moreover, the feeding on sublethal concentrations also reduced their body water contents and at reproductive maturity the aphids were small, light in weight and has less fecundity. The honeydew secretion was also affected negatively (Daniels et al., 2009). Amer and his colleagues tested toxicity of different conventional and neonicotinoide insecticides such as bifenthrin, carbosulfan, methamidophos, thiamethoxam and imidacloprid on aphids and there was a clear difference in effected aphids and control plots (Amer et al., 2010). When generations of $R$. padi were exposed to sublethal doses of insecticides it was noted that their, both fecundity and longevity were significantly decreased after exposure (Lu et al., 2016). This study will be helpful to understand how Carbosulfan changes the biology of aphids at low concentrations and the susceptibility of nymphs of aphids to lower concentrations of insecticide. 


\section{Conflict of interest}

The author declared that they have no conflicts of interest to this interest. The authors declare that they do not have any associative or commercial interest that represents a conflict of interest in connection with the work submitted.

\section{References}

Ahmad, S., Aftab, A., Sabri, M. A., Ghazal, A., Ullah, Z., Ahmad, M. I., Bilal, H., Mohsin, M., and Naz, S. I. (2017). Efficacy of four different insecticides with different mode of action against canola aphid (Lipaphis erysimi) under field condition. J. Entom. \& Zoolo. Studi 5, 626-629.

Akhtar, N., Hashmat, R. T., Jilani, G., Chughtai, S., Irshad, M., and Yasmin, S. (2007). Resistance of different wheat lines to Rhopalosiphum padi (L.)(Aphididae: Homoptera) in Pakistan. Pakistan Journal of Zoology 39, 191.

Amer, M., Aslam, M., Razaq, M., and Shad, S. A. (2010). Effect of conventional and neonicotinoid insecticides against aphids on canola, Brassica napus L. at Multan and Dera Ghazi Khan. Pakistan J. Zool 42, 377-381.

Calafiori, M.H, Barbieri, A.A, Salvo, S., and Desalvo, S. (1999). Efficacy of insecticides for the control of Thrips, Thrips tabaci (Lind.) and Aphid, Aphis gossypi Glover, on Cotton, Gossypium hirsutum. L. Anais II Congresso Brasileiro deAlgodao: O algodao no sculoxx, Perspectives para $\mathrm{O}$ secure XXI, Ribeirao preto, S. P. Brasil 5-10 September 208-211.

Chi, H., (2017). TWOSEX-MS Chart: a Computer Program for the Age-stage, Two-sex Life Table Analysis. National Chung Hsing University, Taichung, Taiwan.

Chinnaiah C \& Asif A K 1999 Seed treatment with Carbosulfan for effective control of sucking pests of cotton. Pestol. 18: 19-23.

Close, R., and Lamb, K. (1961). Trapping study of some winged aphid vectors of plant virus diseases in Canterbury, New Zealand. New Zealand Journal of Agricultural Research 4, 606-618.

Daniels, M., Bale, J., Newbury, H., Lind, R., and Pritchard, J. (2009). A sublethal dose of thiamethoxam causes a reduction in xylem feeding by the bird cherry-oat aphid (Rhopalosiphum padi), which is associated with dehydration and reduced performance. Journal of Insect Physiology 55, 758-765.

Faheem, M., Sajjad, A., Shafique, R., Rehman, A., and Aslam, M. (2016). Field evaluation of different insecticides against wheat aphids and their natural enemies in Pakistan. Asian journal of Agriculture Biology 4.
FAO/WHO (1984). Pesticide residues in food. The monographs data and recommendations of the joint meeting of the FAO Panel of Experts on Pesticide Residues in Food and the Environment and the WHO Expert Group on Pesticide residues. Rome, 24 September -3 October 1984.

Greene, G. L. (1966). Field populations of three grain aphid species in Western Oregon. Journal of Economic Entomology 59, 1201-1206.

Harper, A., and Blakeley, P. (1968). Survival of Rhopalosiphum padi in stored grain during cold weather. Journal of economic entomology.

Kantack, B., and Kieckhefer, R. (1979). Cereal aphids: economic thresholds and losses in South Dakota spring wheat. In "abstr.). In: AJ Howitt [chairman], 57th annual conference of the North Central States entomologist. Proceedings, North Cent. Branch Entomol. Soc. Am", Vol. 33, pp. 20.

Kerns, D. L., and Stewart, S. D. (2000). Sublethal effects of insecticides on the intrinsic rate of increase of cotton aphid. Entomologia Experimentalis et Applicata, 94(1), 41-49.

Lu, Y., Zheng, X., and Gao, X. (2016). Sublethal effects of imidacloprid on the fecundity, longevity, and enzyme activity of Sitobion avenae (Fabricius) and Rhopalosiphum padi (Linnaeus). Bulletin of Entomological Research, 106(4), 551-559.

Prescott, J.M., P.A. Burnett, E.E. Saari et a/. 1986. Wheat Diseases and Pests: A Guide for Field Identification. CIMMYT. Mexico, D.F., Mexico.

Quisenberry, S.S., X. Ni. (2007). Feeding injury, in: H. van Emden, R. Harrington (Eds.), Aphids as Crop Pests, CABI, U.K, 2007: 331-352.

Rautapaa, J., (1968). Reduction in yield and changes in brewing quality of barley caused by Macrosiphum avenae E (Hom. Aphididae). Acta Agric. scand. 18: 233-241.

Roza-Gomes, M. F., Salvadori, J. R., \& Schons, J. (2008). Damage of Rhopalosiphum padi (L.) (Hemiptera: Aphididae) on wheat plants related to duration time and density of infestation. Neotropical entomology, 37(5), 577-581.

Russell, G.E., 1978. Plant breeding for pest and disease resistance. Butterworths, London.

Sawicki, R. M., and Rice, A.D. (1978). Response of susceptible and resistant peach potato aphids Myzus persicae (Sulz.) to insecticides in leaf dip bioassays. Pesticide Science, 9(6), 513516.

[Citation: Ahmad, S., Hera, Z., Hanif, M.S., Syed, A.H., (2020). Effects of carbosulfan on the biology of bird cherry oat aphid. Biol. Clin. Sci. Res. J., 2020: 14 doi: https://doi.org/10.54112/bcsrj.v2020i1.14] 
Torres, J. B., and Ruberson, J. R. (2004). Toxicity of thiamethoxam and imidacloprid to Podisus nigrispinus (Dallas) (Heteroptera: Pentatomidae) nymphs associated to aphid and whitefly control in cotton. Neotropical Entomology, 33(1), 99-106.

Watson, M. A. (1959). Cereal virus diseases in Britain. N.A.A.S. q. Seed Pathology. 93-102.

Watson, M. A., \& Mulligan, T. (1960). The manner of transmission of some barley yellowdwarf viruses by different aphid species. Annals of Applied Biology, 48(4), 711-720.

\section{(c) (†) (8)}

Open Access This article is licensed under a Creative Commons Attribution 4.0 International License, which permits use, sharing, adaptation, distribution and reproduction in any medium or format, as long as you give appropriate credit to the original author(s) and the source, provide a link to the Creative Commons licence, and indicate if changes were made. The images or other third party material in this article are included in the article's Creative Commons licence, unless indicated otherwise in a credit line to the material. If material is not included in the article's Creative Commons licence and your intended use is not permitted by statutory regulation or exceeds the permitted use, you will need to obtain permission directly from the copyright holder. To view a copy of this licence, visit http://creativecommons.org/licen ses/by/4.0/.

(C) The Author(s) 2021

[Citation: Ahmad, S., Hera, Z., Hanif, M.S., Syed, A.H., (2020). Effects of carbosulfan on the biology of bird cherry oat aphid. Biol. Clin. Sci. Res. J., 2020: 14 doi: https://doi.org/10.54112/bcsrj.v2020i1.14] 